\title{
Changes in invertebrate assemblage structure as affected by the flow regulation of a páramo river
}

\author{
Juan David González-Trujillo* and Jhon Ch. Donato-Rondon \\ Universidad Nacional de Colombia - Sede Bogotá - Departamento de Biología - Cra 30 No. 45 - 03, Colombia
}

Received 23 March 2016; Accepted 19 July 2016

\begin{abstract}
Flow regulation can alter the structure and dynamics of lotic communities, especially in rivers with unpredictable high-flow events, such as those flowing through the Páramo, an endemic ecosystem of the high-altitude Neotropical Andes. This study evaluated how flow regulation affects invertebrate assemblage structure in a Páramo river. In both the wet and dry seasons, the study assessed flow history, water chemistry and mesohabitat characteristics in their relation to assemblage structures upstream (undisturbed reach) and downstream (disturbed reach) of a water diversion structure. The elimination of spates through flow regulation did not lead to a complete change in the assemblage components at the disturbed reach. Instead, it led to an assemblage structure with a greater genera-richness, a lower genera-evenness and a greater occurrence of certain genera, e.g., Pristina, Alotanypus, Polypedilum and Austrolimnius. These genera lacked resistance-resilience adaptations, which would allow them to survive in mesohabitat conditions resulting from increased hydromorphological stability, namely higher fine sediment retention, higher benthic organic matter (BOM) and lower hydraulic stress. Overall, the results of this study reinforce the assertion that, in Páramo rivers, the temporal dynamics of the natural flow regime significantly control the structure of invertebrate assemblages. Thus, to preserve these rivers' biotic assemblages, it will be necessary to implement new regulation plans that mimic their natural flow histories.
\end{abstract}

Key words: Flow regulation / Páramo / aquatic invertebrates / flow history / diversion structure / hydromorphological stability

\section{Introduction}

Flow regulation is a global-scale impairment (Rosenberg et al., 2000), which alters the quantity, timing and variability of discharge in streams and rivers (Ward and Stanford, 1995; Nilsson, 2005). Several authors have brought to light that a decrease in temporal flow variability - linked to a decrease in flow magnitude and frequency - can drive changes in sediment and organic matter transport, water chemistry and the structure of invertebrate assemblages (Bunn and Arthington, 2002; Allan and Castillo, 2007; Martínez et al., 2013; Mbaka and Wanjiru Mwaniki, 2015). However, the effects of flow regulation on invertebrate assemblages depend on how this impairment alters their physical habitat (Armitage, 1984; Petts, 1984). Since different flow regimes can regulate physical habitats in different ways (Poff and Ward, 1990), exploring changes in assemblage structure among regulated rivers with different flow regimes is likely to

*Corresponding author: jdgonzalezt@unal .edu.co improve our knowledge of the effects of flow regulation on invertebrate assemblages.

At 3000 m.a.s.1. in the Northern Andes is a unique, endemic ecosystem called the "Páramo." Largely dependent on local precipitation, winds and topography, the flow regime of "Páramo streams" varies with geographical location. Páramos located on the western slopes of the Colombian and Northern Ecuadorean mountains, for instance, receive continuous rain throughout the year, while those further north have marked wet and dry seasons (Vargas and Pedraza, 2004; Buytaert et al., 2006). Nevertheless, a common feature of these high-altitude streams is that they are frequently subject to unpredictable "spates" or high-flow events during rainy seasons, and these events seem to be the main determining factor of the streams' chemical, physical and biological processes (Jacobsen, 2008). Indeed, greater hydraulic stress and streambed movement during highflow events seem to be the main causes of disturbances that alter the structure of invertebrate assemblages at lower spatio-temporal scales (Flecker and Feifarek, 1994; Jacobsen, 2005). 
Páramos have been considered a "priority ecosystem" not only because they are "hotspots" of biodiversity (Myers et al., 2000), but also because a growing number of anthropogenic pressures are threatening their integrity and functioning (Buytaert et al., 2006). Among these, flow regulation has emerged as one of the major threats to the biodiversity and functioning of Páramo streams, since the elimination of high-flow events may enhance hydromorphological stability, thereby affecting invertebrate assemblages in terms of taxa life-history strategies (Resh et al., 1988; Péru and Dolédec, 2010). Some studies have found that key components of life-history strategies (e.g., emergence, drift and colonization) are linked to the dynamics of high-flow events in high-altitude streams (Ríos-Touma et al., 2012; Castro-Rebolledo and Donato-Rondon, 2015). However, knowledge about the effects of flow regulation on invertebrate assemblages in Páramo streams is still scarce, and even more so for those with two distinctive seasons. Therefore, understanding how invertebrate assemblages respond to greater hydromorphological stability may be necessary before we can successfully mitigate the effects of flow regulation.

Improving the management of Páramo streams and rivers, and conserving their inherent biodiversity, will require a deeper understanding of the role and significance of natural flow and the consequences of its regulation on the assemblages in Páramo streams. The primary goal of this study was to assess the effects of flow regulation on macroinvertebrate assemblages in a Páramo river. In order to accomplish this, we analyzed the structure of benthic invertebrate assemblages upstream and downstream of a water diversion structure. We also evaluated whether flow regulation has the same effects during different seasons, and among distinct mesohabitats, i.e., units that combine substrate type with local hydraulic stress. Given that flow regulation enhances hydromorphological stability, we expected more resilient and resistant genera to be replaced by genera adapted to stable flow conditions and that could not survive in-stream changes associated with high-flow events downstream of the diversion structure.

\section{Methods}

\section{Study site}

The study was carried out in the Guatiquia River, a Páramo river formed by the union of three small streams at an elevation of 3500 m.a.s.l. The river flows through Chingaza National Park (Colombia) for approximately $20 \mathrm{~km}$ until it reaches the park border. Inside the park, the river flows through an area covered by typical Páramo vegetation: Espeletia, Polylepis, Chusquea tessellata, Calamagrostis, Hypericum and several species of Bryophytes. This area has the following features typical of tropical, high mountain climates: a mean precipitation of $2522 \mathrm{~mm}$; mean evo-transpiration of $566 \mathrm{~mm}$; and a mean temperature of $9^{\circ} \mathrm{C}$, with high intraday variability.
Additionally, rivers draining the area have two distinguishable seasons: a dry season characterized by a low-flow period between December and February, and a wet season between April and September characterized by the occurrence of unpredictable high-flow events (Vargas and Pedraza, 2004).

Two 60-m long reaches were selected inside Chingaza National Park, one above a diversion structure (San José; $04^{\circ} 32^{\prime} 19.5^{\prime \prime} \mathrm{N}-73^{\circ} 44^{\prime} 40.5^{\prime \prime} \mathrm{W} ; 3180$ m.a.s.l) and one below the structure (Leticia; $04^{\circ} 32^{\prime} 24,1^{\prime \prime} \mathrm{N} ; 37^{\circ} 43^{\prime} 51,4^{\prime \prime} \mathrm{W}$; 3030 m.a.s.l). San José was selected as a "reference reach" because it was thought to reflect the river's flow conditions before the building of the diversion structure. Downstream of the diversion structure, the flow regime has changed from a unimodal distribution to a uniform distribution, i.e., a constant flow throughout the year (Fig. 1). Therefore, only $8 \%$ of the daily flows equaled or exceeded the annual mean flow $\left(0.9 \mathrm{~m}^{3} \cdot \mathrm{s}^{-1}\right)$ over a Julian year. Meanwhile, San José's flow equaled or exceeded this mean flow almost $60 \%$ of the time. We found that the flow regimes at the two reaches had a similar temporal trend before the installation of the diversion structure (González-Trujillo and Donato-Rondon, unpublished data).

\section{Invertebrate sampling}

Invertebrate samples were taken in the wet season (June 30, 2013) and dry season (January 30, 2014) in four mesohabitat types. Mesohabitat types (Armitage and Pardo, 1995; Beisel et al., 2000) were defined as a combination of substrate types and a range of flow velocities that were both visually recognisable within a stream. We established these mesohabitat types because they summarized the possible impact of flow on the invertebrates' physical habitat. For this reason, samples were taken under two different flow conditions and in two different substrate types with different degrees of hydraulic stability: boulders in zones with a range of current velocity of $0.25-0.8$ ("high-flow boulder") or 0.01-0.24 ("low-flow boulder"), or gravel and sand in zones with a range of current velocity of $0.25-0.8$ ("high-flow gravel") or 0.01-0.24 ("low-flow gravel"). For every mesohabitat at each reach, 5 random samples were taken with a Surber $\left(0.09 \mathrm{~m}^{2}, 200 \mu \mathrm{m}\right.$ mesh size $)$. A total of 80 samples were taken $(2$ seasons $\times 2$ reaches $\times 4$ mesohabitats $\times 5$ samples) and preserved individually in $95 \%$ ethanol. In the laboratory, all individuals were identified to the genus level following Domínguez and Fernández (2009) and Prat et al. (2011).

\section{Environmental variables}

At each sampling date, environmental variables related a priori to the river flow regime were measured at mesohabitat and reach level. For each sampled mesohabitat, we measured Froude number, benthic organic 


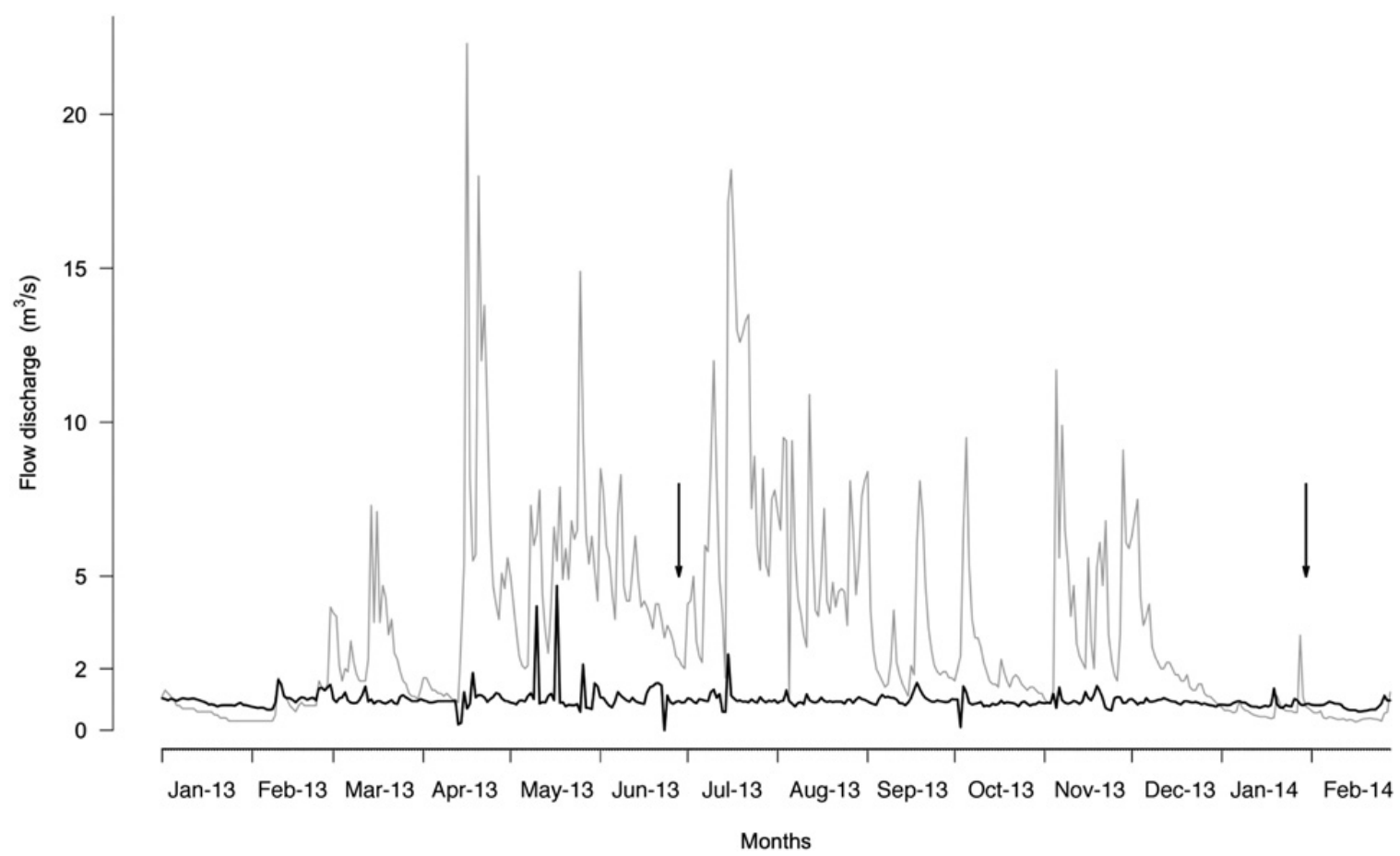

Fig. 1. Hydrograph of daily discharge as a function of sampling date (arrows) for the two study reaches. San José and Leticia daily flows are represented in grey and black, respectively. Data Provided by EAB.

matter (BOM) and the dominant substrate type ("Sust") between cobbles (Particle size $>31 \mathrm{~mm}$ ), gravel (particle size $3-31 \mathrm{~mm}$ ) and sand (particle size $>2 \mathrm{~mm}$ ). The ashfree dry weight of each sample was used as an estimation of the BOM content (Elosegi and Sabater, 2009). The Froude number was calculated using the formula $\mathrm{Fr}=V /\left(g^{*} D\right)^{0.5}$, where $g$ is the acceleration due to gravity, $D$ is water depth, and $V$ is the flow velocity measured by a digital flow meter (SCHILTKNECHT - MiniAir 20). At the reach level, we measured a set of physical-chemical variables in situ using a HACH HQ14D multiparameter: $\mathrm{pH}$, conductivity, temperature and dissolved oxygen ("DO"). Additionally, we used historical flow data to estimate four parameters: the mean of the daily flows 15 days before each sampling ("15_flow"); the coefficient of variation of the daily flows 30 days before each sampling ("CV_flow"); the number of the days since the last high-flow event (a high-flow event was identified as a daily flow equal to or above the P75 of the historical data; "days_after"); and, the mean of all negative differences between consecutive daily values 30 days before each sampling ("freq"). These parameters summarized four of the five components of the flow history (Poff et al., 1997): magnitude, timing, frequency and rate of change. The duration component was not included because of the study's short duration.

\section{Data analyses}

We assessed the changes in structure of invertebrate assemblages betweeen the two reaches and the two seasons using a series of alpha and beta diversity metrics. Alpha indices were used to evaluate the local diversity at the mesohabitat and reach levels. The following indices were estimated for all samples: genera density ("D"); genera richness, defined as the number of genera in a sample ("S"); Shannon-Wiener diversity index ("H" - Shannon, 1948), a descriptor of diversity; Pielou index ("J" - Pielou, 1966), a descriptor of the distribution evenness of individual specimens among genera; and, Berger-Parker index ("d" - Berger and Parker, 1970), a descriptor of the extent of the most abundant genera. Differences in these descriptors (D, S, H, J, d) were tested using a three-way ANOVA model (factors: reach, season and mesohabitat). We used logarithmic-transformed genera density because it was the only variable violating ANOVA assumptions.

Beta diversity metrics were also used to evaluate the degree of dissimilarity among the mesohabitats at each reach over the two seasons. Finding differences among mesohabitats could suggest that flow regulation did not have the same effect over assemblages inhabiting different substrates with dissimilar hydraulic stability. The dissimilarity was measured as the average distance from each sample to its respective centroid using three distance measures (Jaccard, Modified Gower, Euclidean). The centroids were defined in the principal coordinate space of each dissimilarity measure. These measures were selected because they represented a continuum from species (or taxa) composition to relative species abundance data (Anderson et al., 2006). Therefore, we could evaluate how much of the dissimilarity was driven by differences in composition and how much was driven by differences in relative abundance. Finally, spatio-temporal differences 
Table 1. Results of three-way ANOVA tests for genera density, genera richness, Shannon-Wiener index $(\mathrm{H})$, Pielou index $(\mathrm{J})$, and Berger-Parker index (d).

\begin{tabular}{|c|c|c|c|c|c|c|c|c|c|c|c|}
\hline \multirow[b]{2}{*}{ Source } & \multirow[b]{2}{*}{ d.f. } & \multicolumn{2}{|c|}{$\log _{10}$ (Density) } & \multicolumn{2}{|c|}{ Richness } & \multicolumn{2}{|c|}{ Shannon index } & \multicolumn{2}{|c|}{ Pielou index } & \multicolumn{2}{|c|}{ Berger-Parker index } \\
\hline & & $F$ & $P$-value & $F$ & $P$-value & $F$ & $P$-value & $F$ & $P$-value & $F$ & $P$-value \\
\hline Reach & 1 & 77.69 & 0.00001 & 36.8 & 0.00001 & 1.14 & 0.290 & 12.1 & 0.0009 & 0.11 & 0.7360 \\
\hline Season & 1 & 4.07 & 0.0478 & 0.04 & 0.8372 & 6.28 & 0.015 & 6.59 & 0.0126 & 9.15 & 0.0036 \\
\hline Mesohabitat & 3 & 7.95 & 0.0001 & 4.39 & 0.0072 & 2.91 & 0.041 & 3.81 & 0.0141 & 1.86 & 0.1449 \\
\hline Reach $\times$ Season & 1 & 6.52 & 0.0131 & 5.5 & 0.0218 & 1.65 & 0.203 & 0.10 & 0.7519 & 0.35 & 0.5537 \\
\hline Reach $\times$ Mesohabitat & 3 & 2.30 & 0.085 & 6.67 & 0.0001 & 3.02 & 0.036 & 2.04 & 0.1175 & 1.46 & 0.2338 \\
\hline Season $\times$ Mesohabitat & 3 & 4.89 & 0.004 & 3.96 & 0.0118 & 2.75 & 0.050 & 0.31 & 0.8205 & 0.80 & 0.4963 \\
\hline Reach $\times$ Season $\times$ Mesohabitat & 3 & 0.94 & 0.428 & 0.68 & 0.0569 & 0.68 & 0.567 & 0.61 & 0.6105 & 0.68 & 0.5693 \\
\hline Residuals & 64 & & & & & & & & & & \\
\hline Total & 79 & & & & & & & & & & \\
\hline
\end{tabular}

The values in bold are $P$-values below $0.05(P<0.05)$.

in beta diversity between reaches and seasons were evaluated by homogeneity tests in multivariate dispersions (Anderson, 2006). If a signifficant overall $F$-ratio was found when comparing groups $(P$-value $<0.05,9999$ permutations), pairwise comparisons were performed to analyze differences between reaches and mesohabitats over the seasons.

Using redundancy analysis (RDA), the relationship between the environmental variables and the assemblage structure was assessed. To retain only the signifficant environmental variables, a forward selection procedure was followed using the "ordiR2step" function of the Vegan Package (Oksanen et al., 2015) of the R Statistical Program. This function builds a model that maximizes $R_{\text {adj }}^{2}$ at every step until: (1) the adjusted $R_{\text {adj }}^{2}$ starts to decrease, (2) the scope $R_{\text {adj }}^{2}$ is exceeded, or (3) the selected permutation $P$-value is exceeded (Blanchet et al., 2008). Variance inflation factors (VIF) were assessed for each selected variable to prevent multicollinearity between the model's variables. Furthermore, we used a partial RDA analysis to determine how sets of mesohabitat-scale and reach-scale variables explained the variation in the assemblage structure (Borcard et al., 1992). Finally, following Spiesman and Cumming (2008), a set of generalized linear models was used to determine how the occurrence of each genus varied in response to the first RDA axis. All statistical analyses and graphical outputs were computed in the R Statistical Program (Version 3.2.1 - R Development Core Team 2015, available at: www.r-project.org) using the packages "psych", "vegan" and "MASS".

\section{Results}

\section{Assemblage structure}

A total of 15179 individuals from 29 genera in 11 families were identified (Appendix 1). Rarefaction Analysis indicated that the sites were well sampled, as curves for both reaches appeared to approach an asymptote. Chironomidae was the most important family in terms of genera richness, since about half of the identified genera belonged to this family. Chironomidae and Naididae were the predominant families in both seasons. They accounted for 47 and $44 \%$ of the assemblage's total abundance in the wet and dry seasons, respectively.

ANOVA $F$ values indicated that flow regulation had only a significant influence on invertebrate density and richness, and on assemblage evenness. We cannot assert that flow regulation always affect richness and density because the interaction "Reach $\times$ Season" was significant for them (Table 1). However, their average values suggest that flow regulation could lead to a seasonal change in assemblage structure (Fig. 2). Indeed, Season only had a significant influence on invertebrate density at the regulated reach - where density of individuals inhabiting boulders increased more than twice in the dry season. In addition, genera richness was higher at the disturbed reach (mean $11.43 \pm 3.71$ ) than at the undisturbed reach (mean $7.75 \pm 2.87$ ), especially in the dry season.

ANOVA identified significant differences in evenness (Pielou index) due to Season, Reach and Mesohabitat. Evenness was higher at the undisturbed site (mean $0.74 \pm 0.15$ ) than at the disturbed site (mean $0.64 \pm 0.14$ ) during both seasons and tended to decrease at the disturbed site in the dry season (Fig. 2). ANOVA indicated that Season had the strongest influence on the Shannon and Berger-Parker indices. For both indices, the model did not identify a significant difference between the reaches, which suggests that flow regulation does not affect them at all (Table 1).

The homogeneity test for multivariate dispersions indicated that flow regulation led to a significant difference between seasons at the disturbed site (Table 2). These differences were driven by a greater similarity among mesohabitats in terms of genera composition and by a greater dissimilarity among mesohabitats in terms of the relative abundances of the genera (Fig. 3). In this sense, flow regulation allowed the incorporation of different genera at those mesohabitats with low hydraulic stability (e.g., gravel and sand; Fig. 2). This incorporation led to a more "homogenous" assemblage at the disturbed reach. Indeed, the highest similarity of genera composition among mesohabitats was found at the dry season. Conversely, the test did not find a significant difference between the two seasons at the undisturbed reach (Fig. 3). 

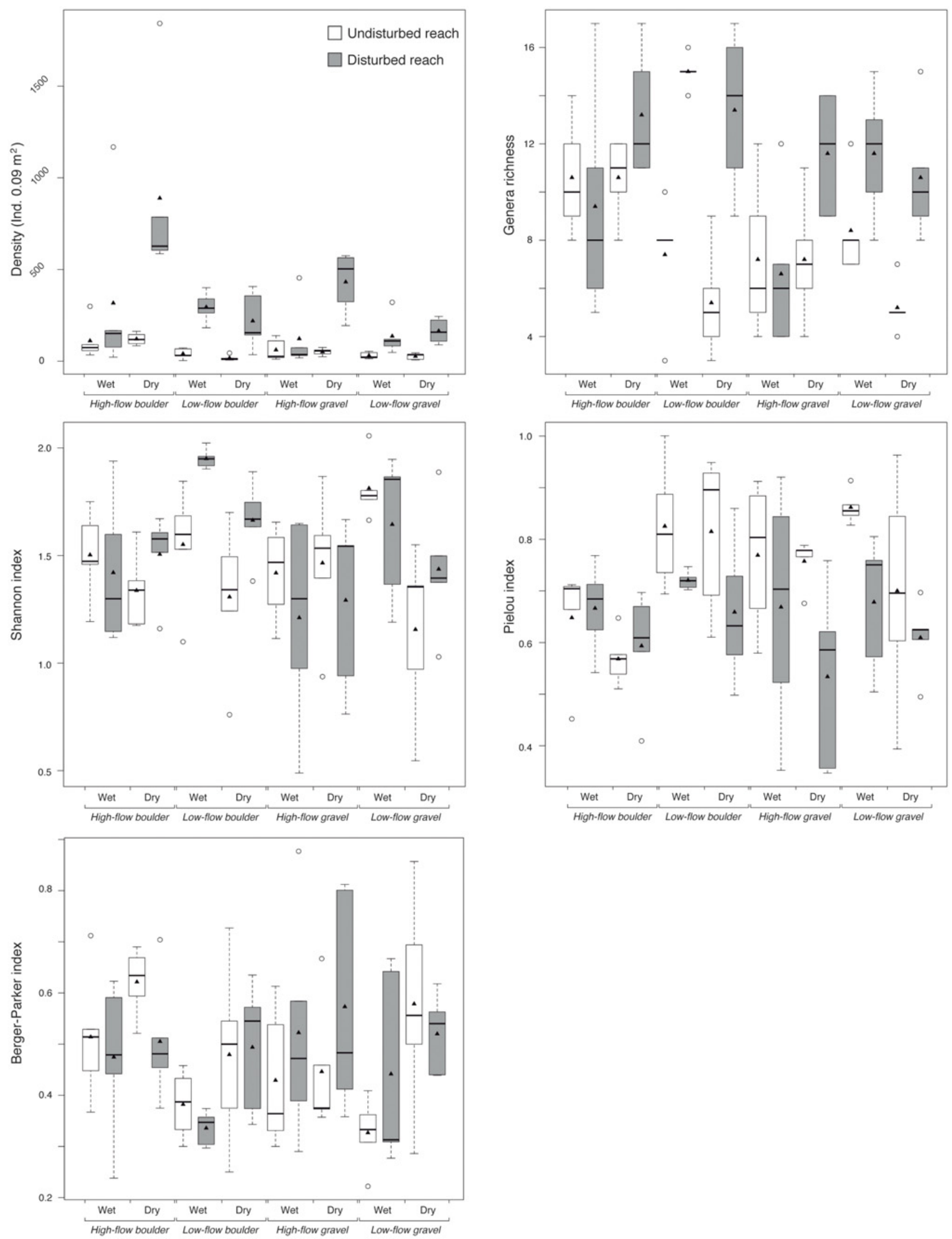

Fig. 2. Box plots for genera density (D), genera richness, diversity (Shannon index), evenness (Pielou index) and dominance (Berger-Parker index) grouped by mesohabitat type and season (dry-wet). Average values have been drawn using black triangles. 
Table 2. Homogeneity test results for multivariate dispersions based on three dissimilarity measures.

\begin{tabular}{lccl}
\hline Distance measure & $F$ & $P$-value & Significant pairwise comparisons \\
\hline Jaccard & 3.1944 & 0.027 & DW-DD/UW-DD/UD-DD \\
Modified gower (Base 10) & 17.177 & $<0.0001$ & UW-DW/UW-DD/UD-DW/UW-DD \\
Euclidean (excluding joint absences) & 9.1344 & $<0.0001$ & UW-DW/UW-DD/UD-DW/DW-DD/UD-DD \\
\hline
\end{tabular}

$\mathrm{UW}$, upstream reach in the wet season; UD, upstream reach in the dry season; DW, downstream reach in the wet season; DD, downstream reach in the dry season. Tests were performed with 9999 permutations.
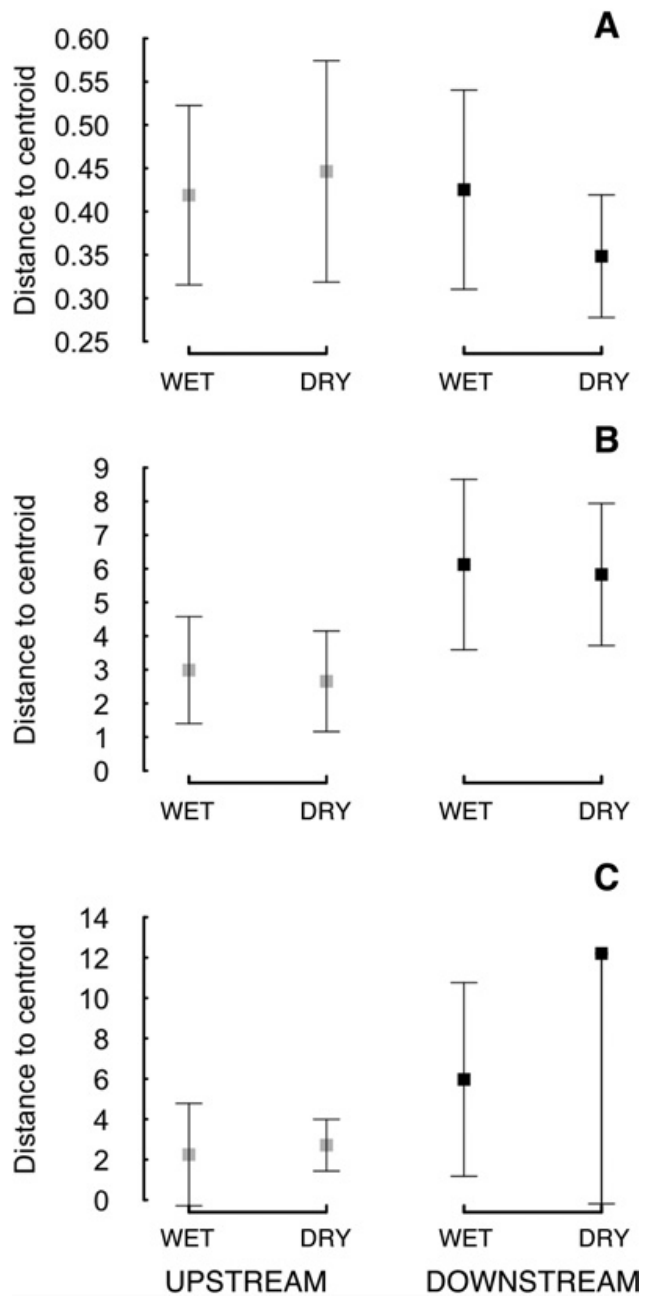

Fig. 3. Average distance to centroid $( \pm 1 \mathrm{SE})$ of invertebrate assemblages classified into each of the four groups according to reach and season. Distances were estimated using Jaccard (A), Modified Gower (Base 10, B) and Euclidean (C) measures.

\section{Environmental variable influences}

The RDA forward selection procedure identified seven significant environmental variables. All of these had a VIF below 3. These variables explained a range of Reach- and Mesohabitat-related variations, and explained $35.9 \%$ of the total genera abundance variability. Results from the partial RDA showed that Mesohabitat-related and Reachrelated variables explained 17.12 and $23.9 \%$ of the total variation, respectively. There was also considerable overlap between these variables $\left(R_{\mathrm{adj}}=0.052\right)$, suggesting that they both influenced assemblage structure.
Ordination along the first RDA axis was mainly determined by mesohabitat substrate type and flow history. Therefore, these factors were important in differentiating the samples according to "Reach" or "Reach $\times$ Mesohabitat", both factors indicating the impact of flow regulation over the assemblages' structure. Several of the Leticia samples were highly correlated to "days-after", "cond", "SustSand" and "BOM". Meanwhile, San José samples tended to be correlated to "CV-flow" and "froude". Some mesohabitat-related variables - such as gravel and cobble substrates - largely constrained the sample distribution along the second RDA axis (Fig. 4). In this way, positive scores of axis 1 reflected a decrease in flow predictability and higher hydraulic stress. On the other hand, negative scores reflected a reduction in flow frequency, and an increase in flow timing (or predictability) and in BOM and small particle retention. From the 29 identified genera, the occurrence of 11 of those significantly responded to the environmental variability explained by the first RDA axis (Fig. 5).

\section{Discussion}

The stochastic nature of high-flow events has been proposed to be the main factor governing the spatial variation of invertebrate assemblages in High-Andean streams (Jacobsen and Encalada, 1998; Jacobsen, 2008). High-flow events or spates are the major source of natural disturbance in these streams, given that spates have a direct effect on the characteristics of the physical habitat of invertebrates (Lake, 2000; Jacobsen, 2005). In the Guatiquia river, the mesohabitat and reach level explained a considerable proportion of the total variance in the RDA model. These findings suggest that the structure of invertebrate assemblages living in this river is shaped by the interaction of factors acting at two distinct scales. Thus, structural differences between the upstream and downstream assemblages were a consequence of a topdown disruption caused by the flow regulation. Firstly, the diversion structure disrupts the timing, magnitude and rate of change of the natural flow regime at the reach level. Secondly, this disruption causes changes of factors at the mesohabitat level - such as hydraulic stress, as well as BOM and sediment composition - that affected invertebrate assemblages.

High-flows directly affect mesohabitat-level factors, such as streambed movement, sediment regime and availability of algae or BOM, which shape the local structure of 


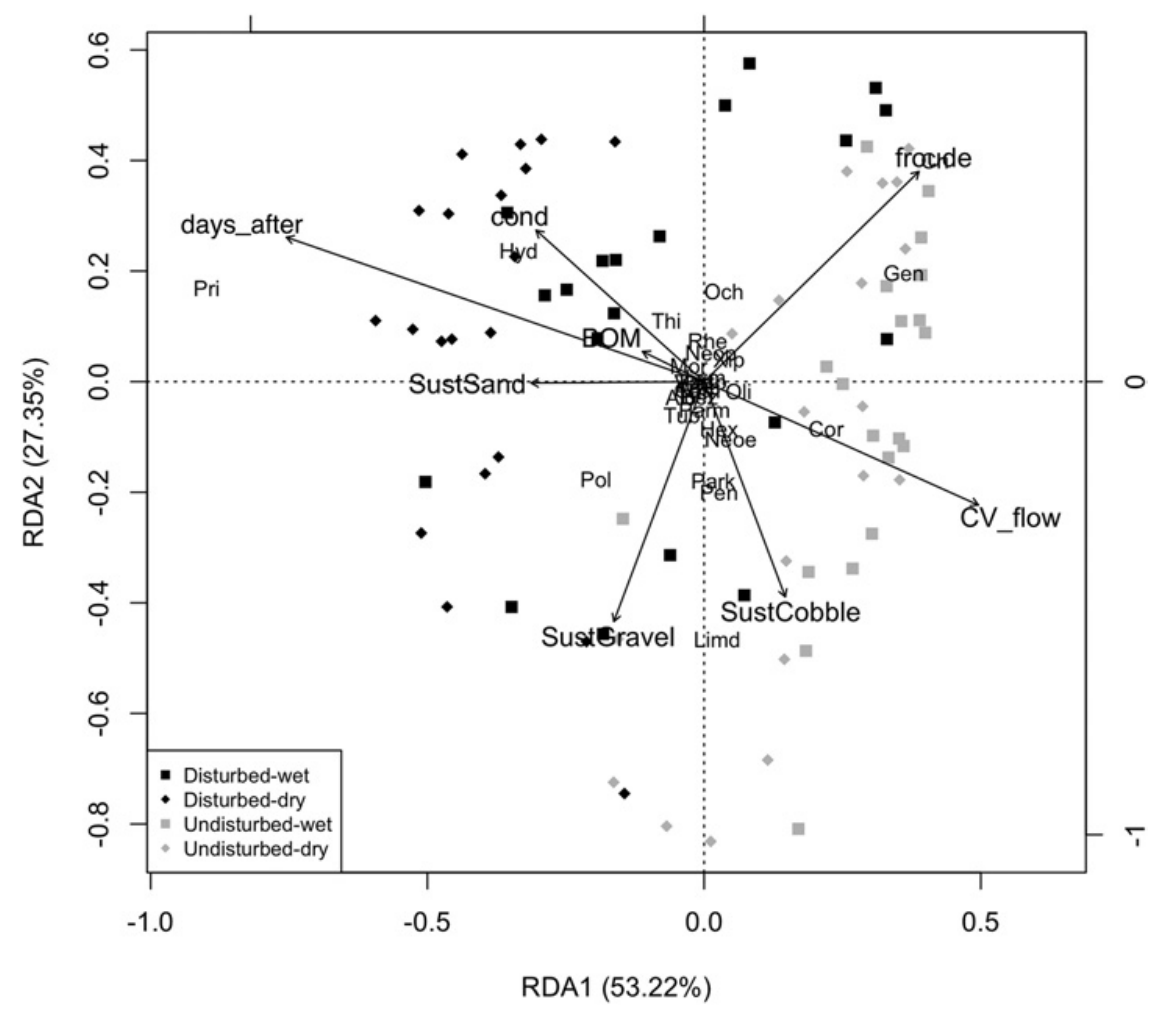

Fig. 4. RDA triplot for the first and second significant axes $(P<0.001)$, scaling 2. Genera data (Hellinger-transformed abundance) constrained by seven significant variables identified by the forward selection procedure are shown. The angle between vectors represents the correlation degree of the environmental variables with the axes, and between themselves.

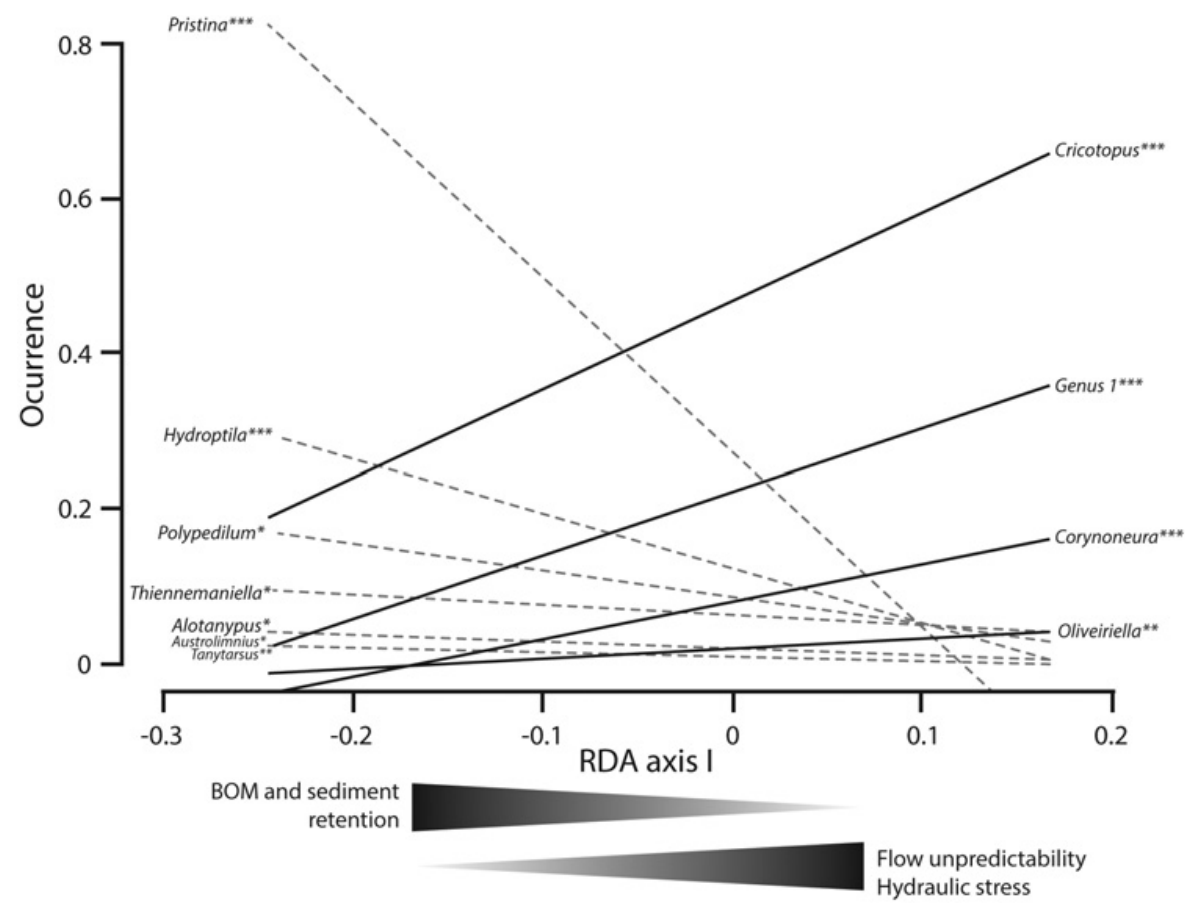

Fig. 5. Genera responses to the first axis of the RDA. Black- and grey-dotted lines show the increase or the decrease of genera occurrence along the axis. Results illustrate the positive and negative effects of flow regulation on the occurrence of some genera of the Guatiquia river. Occurrence data were Hellinger-transformed. The significance of each response was identified by generalized linear models (GLM): ${ }^{*} P<0.05$, ${ }^{* *} P<0.01, * * * P<0.001$. 
invertebrate assemblages by filtering species according to their life-histories (Scarsbrook and Townsend, 1993; Wood and Armitage, 1997; Lamouroux et al., 2004; Merigoux and Doledec, 2004; Buendia et al., 2013). Following this idea, the relationship of assemblage structure with a high frequency of spates, cobble substrates and a high hydraulic stress at the undisturbed reach, suggests that Páramo assemblages are mainly composed of highly "resistant" genera possessing adaptations or strategies that allow them to endure high-flow-induced stressors. In this sense, the assemblage structure after such a high-flow event will be similar to that before the event, because only the "adapted genera" could survive this disturbance event (Minshall and Minshall, 1977; Pickett and White, 1985; Townsend et al., 1997). This restriction explained why we did not identify a seasonal change of assemblage structure at the undisturbed reach, and why we found a greater occurrence of rheophilic genera at this reach, such as some orthocladinae chironomids (e.g., Cricotopus, Corynoneura; Pinder and Reiss, 1983). However, to more fully understand structural responses to the stochastic flow behavior of Páramo rivers, it will be necessary to assess the assemblage structure before and after spates over a longer period of time.

The shifts at the mesohabitat level induced by flow regulation could also explain the structural changes at the disturbed reach. At this reach, assemblages were mainly composed of genera whose fitness is enhanced in conditions of greater hydromorphological stability, i.e., low hydraulic stress, higher BOM and sand availability. In general, it was possible to find a particularity in the lifehistory of these genera that increased their occurrence at the regulated reach. Greater stability and food availability in gravel, could benefit Alotanypus, and other members of Tanypodinae, since they have been recorded mainly as predators and burrowers inhabiting fine sediments in zones with low current velocity (Pinder and Reiss, 1983; Tejerina and Malizia, 2012). The low hydraulic stress could also encourage the presence of other burrowers such as Polypedilum or Austrolimnius. The presence of hemoglobin allows Polypedilum to survive more successfully in spite of the low oxygen concentrations in the sand substrates (Heinis et al., 1994), where it was mainly found. The compact and heavily sclerotized body of Austrolimnius allows it to inhabit depositional zones composed of gravel or sand substrates (Brown, 1987). Finally, the high occurrence of oligochaeta, and specifically, of Pristina at the disturbed reach could be explained by its lack of adaptation to water flow constraints. Moreover, the diet of these genera and of Hydroptila included Cyanobacteria and filamentous algae, which were abundant in boulders at the undisturbed reach (Donato-Rondón, personal observations). The other genera did not have a perceptible or literature-reported life-history, which helps to explain the differences in their occurrences. In light of this, applying a trait-based approach could lead to a greater understanding of biological responses in relation to flow regulation.

Although both reaches showed different environmental conditions at reach and mesohabitat level due to flow regulation, these differences did not drive a complete turnover of genera composition. Instead, they allowed the increase in density of genera without specific resistanceresilience adaptations. As a result, we found at the regulated reach an uneven assemblage with greater richness, which was composed mainly of genera: (i) without adaptations to flow constrains, and (ii) with adaptations to live in gravel or sand. Furthermore, the higher similarity among mesohabitats in the dry season - only in terms of genera composition - suggests that structural changes caused by flow regulation were also driven by the increase in density of those genera with capabilities to swim and colonize in conditions of greater hydromorphological stability (aquatic active dispersion). These results are different from those found in Ecuadorian Páramo streams, where flow regulation was found to not alter the natural seasonal changes in the assemblage structure (Ríos-Touma et al., 2011; Rosero, 2011). Notwithstanding, this difference in findings might be due to the level of taxonomic identification, since, in the current study, almost half the genera identified were chironomids, whereas those in the Ecuadorian studies were midges at family or subfamily level.

Our results suggest that the flow regime could be the main factor constraining the structure of invertebrate assemblages in Páramo rivers. The high number of spates seems to restrict the occurrence of genera that could have adaptations that confer them a higher resistance or resilience to the effects of spates. The elimination of spates by flow regulation seems to enhance the establishment and growth of genera without resistance/resilience adaptations, which also exploit the habitat conditions resulting from the higher hydromorphological stability. The observed patterns suggest that a new regulation plan should be implemented to conserve the natural biodiversity of this Páramo stream. To achieve this goal, it could be necessary to establish a new regulation plan that mimics the stochastic flow of these streams.

Acknowledgements. We wish to thank the two anonymous reviewers for their helpful comments on the manuscript, and Neil Hunt for correcting the English text. Special thanks to Santiago Gaviria for their help determining the oligochaeta specimens. Finally, we also wish to thank Parques Nacionales Naturales (PNN) for providing the access to Chingaza's natural park. The present paper was developed as a part of the Scientific and Technological Agreement (No. 1-07-24300-0832-2012 EAAB-ESP - UNAL) between "Empresa de Acueducto y Alcantarillado (Empresa de Acueducto de Bogotá)" and "Universidad Nacional de Colombia".

\section{References}

Allan J.D. and Castillo M.M., 2007. Stream Ecology: Structure and Function of Running Waters, Springer, Dordrecht.

Anderson M.J., 2006. Distance-based tests for homogeneity of multivariate dispersions. Biometrics 62, 245-253. doi: $10.1111 / \mathrm{j} .1541-0420.2005 .00440 . x$. 
Anderson M.J., Ellingsen K.E. and McArdle B.H., 2006. Multivariate dispersion as a measure of beta diversity. Ecol. Lett., 9, 683-693. doi: 10.1111/j.1461-0248.2006.00926.x.

Armitage P.D., 1984. 'Environmental changes induced by stream regulation and their effect on lotic macroinvertebrate communities. In: Lillehammer A. and Saltveit S.J. (eds.), Regulated Rivers, Oslo University Press, Oslo, Norway, 139-165.

Armitage P.D. and Pardo I., 1995. Impact assessment of regulation at the reach level using macroinvertebrate information from mesohabitats. Regul. Rivers Res. Manag., 10, 147-158. doi: 10.1002/rrr.3450100210.

Beisel J.N., Usseglio-Polatera P. and Moreteau J.C., 2000. The spatial heterogeneity of a river bottom: a key factor determining macroinvertebrate communities. In: Jungwirth, M., Muhar, S. and Schmutz, S. (eds.), Assessing the Ecological Integrity of Running Waters, Springer, Netherlands, 163-171.

Berger W.H. and Parker F.L., 1970. Diversity of planktonic foraminifera in deep-sea sediments. Science, 168, 1345-1347. doi: 10.1126/science.168.3937.1345.

Blanchet F.G., Legendre P. and Borcard D., 2008. Forward selection of explanatory variables. Ecology, 89, 2623-2632.

Borcard D., Legendre P. and Drapeau P., 1992. Partialling out the spatial component of ecological variation. Ecology, 73, 1045. doi: $10.2307 / 1940179$.

Brown H., 1987. Biology of riffle beetles. Annu. Rev. Entomol., 32, 253-273.

Buendia C., Gibbins C.N., Vericat D. and Batalla R.J., 2013. Effects of flow and fine sediment dynamics on the turnover of stream invertebrate assemblages: effects of fine sediment dynamics on beta-diversity of stream invertebrates. Ecohydrology, 1105-1123. doi: 10.1002/eco.1443.

Bunn S.E. and Arthington A.H., 2002. Basic principles and ecological consequences of altered flow regimes for aquatic biodiversity. Environ. Manage., 30, 492-507. doi: 10.1007/ s00267-002-2737-0.

Buytaert W., Célleri R., De Bièvre B., Cisneros F., Wyseure G., Deckers J. and Hofstede R., 2006. Human impact on the hydrology of the Andean páramos. Earth-Sci. Rev., 79, 53-72. doi: 10.1016/j.earscirev.2006.06.002.

Castro-Rebolledo M.I. and Donato-Rondon J.C., 2015. Emergence patterns in tropical insects: the role of water discharge frequency in an Andean Stream. Ann. Limnol. - Int. J. Lim., 51, 147-155. doi:10.1051/limn/2015011.

Domínguez E. and Fernández H.R., 2009. Macroinvertebrados bentónicos sudamericanos: Sistemática y biología. Fundación Miguel Lillo Tucumán, Tucumán, Argentina.

Elosegi A. and Sabater S. (eds.), 2009. Conceptos y técnicas en ecología fluvial. Fundacion BBVA, Bilbao, España.

Flecker A.S. and Feifarek B., 1994. Disturbance and the temporal variability of invertebrate assemblages in two Andean streams. Freshw. Biol., 31, 131-142. doi: 10.1111/ j.1365-2427.1994.tb00847.x.

Heinis F., Sxeerts J.-P. and Loopik E., 1994. Micro-environment of chironomid larvae in the littoral and profundal zones of Lake Maarsseveen I, The Netherlands. Arch. Hydrobiol., 130, 53-67.

Jacobsen D., 2005. Temporally variable macroinvertebratestone relationships in streams. Hydrobiologia, 544, 201-214.

Jacobsen D., 2008. Tropical high-altitude streams. In: Dudgeon D. (ed.), Tropical Stream Ecology, Academic Press, Oxford, UK, 219-256.
Jacobsen D. and Encalada A., 1998. The macroinvertebrate fauna of Ecuadorian highland streams in the wet and dry season. Arch. Hydrobiol., 142, 53-70.

Lake P.S., 2000. Disturbance, patchiness, and diversity in streams. J. North Am. Benthol. Soc., 19, 573. doi: 10.2307/ 1468118.

Lamouroux N., Dolédec S. and Gayraud S., 2004. Biological traits of stream macroinvertebrate communities: effects of microhabitat, reach, and basin filters. J. North Am. Benthol. Soc., 23, 449-466. doi: 10.1899/0887-3593(2004)023 $<0449$ :BTOSMC > 2.0.CO;2.

Martínez A., Larrañaga A., Basaguren A., Pérez J., MendozaLera C. and Pozo J., 2013. Stream regulation by small dams affects benthic macroinvertebrate communities: from structural changes to functional implications. Hydrobiologia, 711, 31-42. doi:10.1007/s10750-013-1459-z.

Mbaka J.G. and Wanjiru Mwaniki M., 2015. A global review of the downstream effects of small impoundments on stream habitat conditions and macroinvertebrates. Environ. Rev., 23, 257-262. doi: 10.1139/er-2014-0080.

Merigoux S. and Doledec S., 2004. Hydraulic requirements of stream communities: a case study on invertebrates. Freshw. Biol., 49, 600-613. doi:10.1111/j.1365-2427.2004. 01214.x.

Minshall G.W. and Minshall J.N., 1977. Microdistribution of benthic invertebrates in a Rocky Mountain (USA) stream. Hydrobiologia, 55, 231-249.

Myers N., Mittermeier R.A., Mittermeier C.G., Da Fonseca G.A. and Kent J., 2000. Biodiversity hotspots for conservation priorities. Nature, 403, 853-858.

Nilsson C., 2005. Fragmentation and flow regulation of the world's large river systems. Science, 308, 405-408. doi: 10.1126/science. 1107887.

Oksanen J., Blanchet F.G., Kindt R., Legendre P., Minchin P.R., O'Hara R.B., Simpson G.L., Solymos P., Stevens M.H.H. and Wagner H., 2015. Vegan: Community Ecology Package.

Péru N. and Dolédec S., 2010. From compositional to functional biodiversity metrics in bioassessment: a case study using stream macroinvertebrate communities. Ecol. Indic., 10, 1025-1036. doi: 10.1016/j.ecolind.2010. 02.011 .

Petts G.E., 1984. Impounded Rivers: Perspectives for Ecological Management, Environmental Monographs and Symposia, Wiley, Chichester [West Sussex], New York.

Pickett S.T. and White P.S. (eds.), 1985. The Ecology of Natural Disturbance and Patch Dynamics, Academic Press, Orlando, Fla.

Pielou E.C., 1966. The measurement of diversity in different types of biological collections. J. Theor. Biol., 13, 131-144. doi: 10.1016/0022-5193(66)90013-0.

Pinder L. and Reiss F., 1983. The larvae of Chironominae (Diptera, Chironomidae) of the Holarctic region-keys and diagnoses. Entomol. Scand., 293-435.

Poff N.L. and Ward J.V., 1990. Physical habitat template of lotic systems: recovery in the context of historical pattern of spatiotemporal heterogeneity. Environ. Manage., 14, 629-645. doi:10.1007/BF02394714.

Poff N.L., Allan J.D., Bain M.B., Karr J.R., Prestegaard K.L., Richter B.D., Sparks R.E. and Stromberg J.C., 1997. The natural flow regime. BioScience, 47, 769-784. doi: 10.2307/ 1313099. 
Prat N., Rieradevall M., Acosta R. and Villamarín C., 2011. Guía para el reconocimiento de las larvas de chironomidae (Diptera) de los ríos altoandinos de Ecuador y Perú.

Resh V.H., Brown A.V., Covich A.P., Gurtz M.E., Li H.W., Minshall G.W., Reice S.R., Sheldon A.L., Wallace J.B. and Wissmar R.C., 1988. The role of disturbance in stream ecology. J. North Am. Benthol. Soc., 7, 433-455.

Ríos-Touma B., Encalada A.C. and Prat Fornells N., 2011. Macroinvertebrate assemblages of an andean high-altitude tropical stream: the importance of season and flow. Int. Rev. Hydrobiol., 96, 667-685. doi: 10.1002/iroh.201111342.

Ríos-Touma B., Prat N. and Encalada A., 2012. Invertebrate drift and colonization processes in a tropical Andean stream. Aquat. Biol., 14, 233-246. doi:10.3354/ab00399.

Rosenberg D.M., McCully P. and Pringle C.M., 2000. Globalscale environmental effects of hydrological alterations: introduction. BioScience, 50, 746-751.

Rosero D., 2011. Impacto de las capacitaciones de agua en la integridad ecológica y posibles soluciones para el manejo del flujo de agua en ríos de páramo. (bachelorThesis). Universidad San Francisco de Quito.

Scarsbrook M.R. and Townsend C.R., 1993. Stream community structure in relation to spatial and temporal variation: a habitat templet study of two contrasting New Zealand streams. Freshw. Biol., 29, 395-410.
Shannon C.E., 1948. A mathematical theory of communication. Bell Syst. Tech. J., 27, 379-423.

Spiesman B.J. and Cumming G.S., 2008. Communities in context: the influences of multiscale environmental variation on local ant community structure. Landsc. Ecol., 23, 313-325. doi:10.1007/s10980-007-9186-3.

Tejerina E.G. and Malizia A., 2012. Chironomidae (Diptera) larvae assemblages differ along an altitudinal gradient and temporal periods in a subtropical montane stream in Northwest Argentina. Hydrobiologia, 686, 41-54. doi: 10.1007/s10750-011-0984-X.

Townsend C.R., Scarsbrook M.R. and Dolédec S., 1997. Quantifying disturbance in streams: alternative measures of disturbance in relation to macroinvertebrate species traits and species richness. J. North Am. Benthol. Soc., 531-544.

Vargas O. and Pedraza P., 2004. Parque Nacional Natural Chingaza.

Ward J.V. and Stanford J.A., 1995. Ecological connectivity in alluvial river ecosystems and its disruption by flow regulation. Regul. Rivers Res. Manag., 11, 105-119. doi: 10.1002/ rrr.3450110109.

Wood P.J. and Armitage P.D., 1997. Biological effects of fine sediment in the lotic environment. Environ. Manage., 21, 203-217. doi: 10.1007/s002679900019.

Appendix 1. Mean abundance $( \pm 1 \mathrm{SD})$ of the invertebrate genera at the Guatiquia river reaches.

\begin{tabular}{|c|c|c|c|c|c|c|c|c|c|c|}
\hline \multirow[b]{3}{*}{ Order } & \multirow[b]{3}{*}{ Family } & \multirow[b]{3}{*}{ Genus } & \multicolumn{4}{|c|}{ Disturbed reach } & \multicolumn{4}{|c|}{ Undisturbed reach } \\
\hline & & & \multicolumn{2}{|c|}{ Wet season } & \multicolumn{2}{|c|}{ Dry season } & \multicolumn{2}{|c|}{ Wet season } & \multicolumn{2}{|c|}{ Dry season } \\
\hline & & & Mean & $\overline{\mathrm{SD}}$ & Mean & SD & Mean & SD & Mean & $\mathrm{SD}$ \\
\hline \multirow[t]{3}{*}{ Annelida } & Naididae & Limnodrilus & 7.7 & 10.0 & 25.4 & 40.4 & 4.7 & 7.9 & 26.8 & 38.7 \\
\hline & & Pristina & 3.7 & 4.5 & 210.3 & 282.1 & 3.0 & 1.4 & 64.8 & 72.1 \\
\hline & & Tubifex & 1.0 & 0.0 & 1.7 & 0.8 & 1.5 & 0.7 & 3.0 & 2.5 \\
\hline \multirow[t]{2}{*}{ Coleoptera } & Elmidae & Austrolimnius & 1.0 & 0.0 & 2.0 & 0.0 & 1.0 & 0.0 & 2.5 & 1.3 \\
\hline & & Neoelmis & 1.5 & 0.7 & 2.0 & 0.8 & 1.8 & 1.7 & 4.4 & 2.9 \\
\hline \multirow[t]{17}{*}{ Diptera } & Ceratopogonidae & cf. Bezzia & 1.5 & 0.7 & 1.8 & 0.4 & 1.3 & 0.6 & 1.3 & 0.5 \\
\hline & Chironomidae & Alotanypus & 1.0 & 0.0 & 2.8 & 3.1 & - & - & 1.7 & 0.6 \\
\hline & & Corynoneura & 1.1 & 0.4 & 1.3 & 0.5 & 5.2 & 5.0 & 1.0 & 0.0 \\
\hline & & Cricotopus & 12.6 & 13.7 & 27.3 & 35.1 & 12.0 & 17.0 & 22.2 & 27.2 \\
\hline & & Genus 1 & 6.1 & 4.9 & 16.4 & 18.2 & 5.7 & 6.5 & 17.6 & 27.5 \\
\hline & & Lymnophyes & 1.0 & 0.0 & 2.0 & 0.0 & 1.0 & 0.0 & - & - \\
\hline & & Morfo $X$ & 1.0 & 0.0 & 2.0 & 1.7 & 1.0 & 0.0 & 3.8 & 2.4 \\
\hline & & Oliveiriella & 1.5 & 1.0 & - & - & 1.2 & 0.4 & - & - \\
\hline & & Parakiefferiella & 9.9 & 7.8 & 27.1 & 22.5 & 6.0 & 9.6 & 34.6 & 63.6 \\
\hline & & Parametriocnemus & 2.0 & 0.8 & 1.5 & 0.5 & 1.5 & 0.6 & 6.0 & 4.5 \\
\hline & & Pentaneura & 1.0 & 0.0 & 3.2 & 2.3 & 4.3 & 2.7 & 14.1 & 13.3 \\
\hline & & Polypedilum & 2.1 & 1.7 & 23.7 & 32.3 & - & - & 1.8 & 1.0 \\
\hline & & Rheotanytarsus & 3.4 & 3.3 & 12.4 & 12.6 & 5.2 & 9.8 & 16.9 & 31.5 \\
\hline & & Tanytarsus & - & - & 1.3 & 0.6 & - & - & 2.0 & 1.0 \\
\hline & & Thiennemaniella & 2.5 & 1.8 & 8.9 & 9.4 & 1.3 & 0.5 & 2.7 & 2.7 \\
\hline & Empididae & Neoplasta & 2.3 & 2.3 & 1.4 & 0.5 & 3.3 & 4.5 & 3.7 & 5.2 \\
\hline & Tipulidae & Hexatoma & 1.0 & 0.0 & - & - & 1.0 & 0.0 & 1.0 & 0.0 \\
\hline \multirow[t]{3}{*}{ Ephemeroptera } & Baetidae & Camelobaetidius & - & - & 1.8 & 1.0 & 1.0 & 0.0 & 2.0 & 0.0 \\
\hline & & Varipes & - & - & 2.0 & 1.0 & - & - & 2.3 & 1.5 \\
\hline & Leptohyphidae & Vacupernius & - & - & 1.5 & 0.7 & 1.0 & 0.0 & - & - \\
\hline \multirow[t]{4}{*}{ Trichoptera } & Hydrobiosidae & Atopsyche & 1.0 & 0.0 & 2.0 & 1.4 & 1.0 & 0.0 & 2.6 & 3.2 \\
\hline & Hydroptilidae & Hydroptila & 3.0 & 2.6 & 29.7 & 42.2 & 1.0 & 0.0 & 6.5 & 5.1 \\
\hline & & Ochrotrichia & 2.3 & 2.3 & 6.5 & 6.4 & 3.8 & 2.6 & 12.8 & 37.2 \\
\hline & Xiphocentronidae & c.f. Xiphocentron & 8.0 & 0.0 & 1.3 & 0.5 & 3.0 & 2.8 & 3.5 & 2.1 \\
\hline
\end{tabular}

